Agric. Biol. Chem., 42 (5), 971 980, 1978

\title{
Purification and Properties of $\alpha$-Glucosidase and Glucoamylase from Lentinus edodes (Berk.) Sing.
}

\author{
Yoshiki YamaSaki and Yukio SuzukI \\ Institute for Agricultural and Biological Sciences, Okayama University, \\ Kurashiki, Okayama \\ Received October 24, 1977
}

\begin{abstract}
An $\alpha$-glucosidase and a glucoamylase have been isolated from fruit bodies of Lentinus edodes (Berk.) Sing., by a procedure including fractionation with ammonium sulfate, DEAEcellulose column chromatography, and preparative gel electrofocusing. Both of them were homogeneous on gel electrofocusing and ultracentrifugation. The molecular weight of $\alpha-$ glucosidase and glucoamylase was 51,000 and 55,000 , respectively. The $\alpha$-glucosidase hydrolyzed maltose, maltotriose, phenyl $\alpha$-maltoside, amylose, and soluble starch, but did not act on sucrose. The glucoamylase hydrolyzed maltose, maltotriose, phenyl $\alpha$-maltoside, soluble starch, amylose, amylopectin, and glycogen, glucose being the sole product formed in the digests of these substrates. Both enzymes hydrolyzed phenyl $\alpha$-maltoside into glucose and phenyl $\alpha$-glucoside. The glucoamylase hydrolyzed soluble starch, amylose, amylopectin, and glycogen, converting them almost completely into glucose. It was found that $\beta$-glucose was liberated from amylose by the action of glucoamylase, while $\alpha$-glucose was produced by the $\alpha$-glucosidase.

Maltotriose was the main $\alpha$-glucosyltransfer product formed from maltose by the $\alpha$ glucosidase.
\end{abstract}

In the previous papers, ${ }^{1 \sim 7)}$ we have reported the purification and properties of $\alpha$-glucosidases from Mucor javanicus, $M$. racemosus, Penicillium purpurogenum, Pen. oxalicum, and Aspergillus awamori, and those of glucoamylases from $M$. rouxianus, Pen. oxalicum, and Asp. awamori. $\alpha$-Glucosidases from Asp. niger, ${ }^{8)}$ Asp. oryzae, ${ }^{9)}$ and $M$. javanicus ${ }^{1)}$ have so far been isolated in crystalline form. Glucoamylases from Rhizopus delemar, ${ }^{10)}$ Asp. awamori ${ }^{11)}$ Asp. niger, ${ }^{12)}$ Endomyces sp. ${ }^{13)}$ and $M$. rouxianus ${ }^{6}$ ) have so far been isolated in crystalline form.

The enzymes from Basidomycetes have not been studied in the same detail as those from the fungi belonging to Phycomycetes and Ascomycetes.

In the present study, $\alpha$-glucosidase and glucoamylase from fruit bodies of Lentinus edodes (Berk.) Sing. ("shiitake") were isolated in highly purified forms, and their properties were investigated. The results obtained are given here.

\section{MATERIALS AND METHODS}

Materials. Fruit bodies of Lentinus edodes (Berk.) Sing. used were obtained from the local greengrocer's shop. A glucoamylase from Rhizopus niveus (pure grade) and a crystalline a-amylase from Bacillus subtilis (saccharifying type) were purchased from Seikagaku Kogyo Co., Ltd., Tokyo, Japan. Amylose (EX-I, $\overline{\mathrm{DPn}}$. approx. 18), isomaltose, maltose and maltotriose (Hayashibara Biochemical Laboratories, Inc., Okayama, Japan), amylopectin from waxy maize (Nippon Food Industries, Ltd., Tokyo, Japan), glycogen from shellfish (Nakarai Chemicals Co., Ltd., Kyoto, Japan), soluble starch (E. Merck, Darmstadt, Germany), corn starch and potato starch (Wako Pure Chemical Industries, Ltd, Osaka, Japan), rice starch (Shimada Chemical Industries, Ltd., Nigata, Japan) were obtained from commercial sources. Panose was a gift from Prof. K. Matsuda, Faculty of Agriculture, Tohoku University. Other chemicals and reagents used in this study were the same as described in the previous papers. ${ }^{1 \sim 7}$ )

\section{Analytical techniques}

Enzyme assays. $\alpha$-Glucosidase activity was determined by measuring the amount of glucose liberated from the substrate according to the method of Papadopoulos et al., ${ }^{14)}$ as modified by Dahlquist. ${ }^{13)}$ One 
unit of $\alpha$-glucosidase activity is defined as the amount of enzyme which forms $1 \mu$ mole of glucose from maltose per $15 \mathrm{~min}$ under the standard conditions. ${ }^{1)}$ Glucoamylase activity was determined under the same conditions as employed in the assay for the $\alpha$-glucosidase activity, except that soluble starch was used in place of maltose. ${ }^{\text {) }}$

Determination of protein. Protein was determined by the method of Warburg et al. ${ }^{17}$ ) The protein profiles in column chromatography were followed by measuring the absorbance of eluates at $280 \mathrm{~nm}$.

Gel electrofocusing. Analytical gel electrofocusing was performed with $7.5 \%$ polyacrylamide gels containing the carrier ampholyte ( $\mathrm{pH}$ range, 4 to 6 ) according to the method of Wrigley. ${ }^{13)}$ A sample gel containing the purified enzyme was photopolymerized on the top of separation gel, and electrofocusing was run at a constant voltage of $80 \mathrm{~V}$ for $48 \mathrm{hr}$ at $4^{\circ} \mathrm{C}$ using a conventional disc electrophoretic apparatus. Gel was stained for 1 hr with $0.2 \%$ bromphenol blue in ethyl alcohol-water-acetic acid (50:45:5, v/v) and destained with ethyl alcohol-water-acetic acid $(30: 65$ : $5, v / v)$.

Dodecyl sulfate-polyacrylamide gel electrophoresis. For the determination of the molecular weight, the enzyme and markers were separately subjected to electrophoresis by the method of Weber et al., ${ }^{19)}$ with the use of polyacrylamide gel containing sodium dodecyl sulfate at a concentration of $0.1 \%$. The markers used were lysozyme (mol. wt. 14,307), sperm whale myoglobin (mol. wt. 17,800), beef pancreas chymotrypsinogen A (mol. wt. 25,000), ovalbumin (mol. wt. 45,000), and bovine serum albumin (mol. wt. $67,000)$

Paper chromatography. Samples were spotted on a Toyo No. 50 filter paper, and the paper was developed three times at $26^{\circ} \mathrm{C}$ by the ascending method with the solvent system of $n$-butyl alcohol-pyridine-water ( $6: 4$ : $3, v / v)$. After drying, the products were detected by the silver nitrate dip method. ${ }^{20)}$

Analytical ultracentrifugation. Ultracentrifugal studies were performed with a Hitachi model 282 analytical ultracentrifuge.

Oxidation of amylose. Amylose EX-I $(1 \mathrm{~g})$ was oxidized according to the method of J. J. Marshall et al., ${ }^{21)}$ except that sodium metaperiodate $(0.15 \mathrm{~g})$ was added to the amylose solution and the mixture was stored in the dark for 15 hr.

\section{RESULTS}

\section{Purification of $\alpha$-glucosidase}

Unless otherwise indicated, the operations were carried out at $4^{\circ} \mathrm{C}$.

Step 1. Preparation of crude extract. Fruit bodies of $L$. edodes (Berk.) Sing. $(5 \mathrm{~kg})$ were homogenized in a National model MX$120 \mathrm{~S}$ mixer with 10 liters of $0.02 \mathrm{M}$ acetate buffer, pH 5.3 , containing $10 \%$ sodium chloride. The mixture was left overnight at $4{ }^{\circ} \mathrm{C}$ and the mycelial debris was removed by filtration.

Step 2. Fractionation with ammonium sulfate. To the filtrate (14 liters) was added solid ammonium sulfate to give $95 \%$ saturation under stirring. After allowing to stand overnight, the resulting precipitate was collected by filtration, and dissolved in $0.05 \mathrm{M}$ acetate buffer, $\mathrm{pH}$ 5.3. Insoluble material was removed by centrifugation, and solid ammonium sulfate was added to the solution to give $55 \%$ saturation. The resultant precipitate (Fraction I) was collected by centrifugation. The ammonium sulfate concentration of the supernatant solution was then brought to $60 \%$ saturation, and the precipitate was discarded. To the supernatant solution was added solid ammonium sulfate to give $90 \%$ saturation, and the precipitate (Fraction II) was collected by centrifugation. Fractions I and II were dissolved in $0.05 \mathrm{M}$ acetate buffer, $\mathrm{pH}$ 5.3, separately. Each fraction was dialyzed overnight against $0.01 \mathrm{M}$ acetate buffer, $\mathrm{pH}$ 5.3.

\section{Step 3. DEAE-cellulose column chromato-} graphy. Fraction II, after being dialyzed, was applied to a DEAE-cellulose column $(1.8 \phi \times$ $10 \mathrm{~cm}$ ) equilibrated previously with $0.025 \mathrm{M}$ Tris- $\mathrm{HCl}$ buffer, $\mathrm{pH}$ 7.42. Elution was carried out with $0.02 \mathrm{M}$ acetate buffer, pH 5.3 (Fig. 1). The active fractions (Nos. 16 to 38 ) were collected, and solid ammonium sulfate was added to the solution to give $95 \%$ saturation. Any other active fraction was not obtained from the eluate with a linear gradient with 0 to $0.5 \mathrm{M}$ sodium chloride in the same buffer. The resulting precipitate was collected by centrifugation and dissolved in $0.05 \mathrm{~m}$ acetate buffer, 


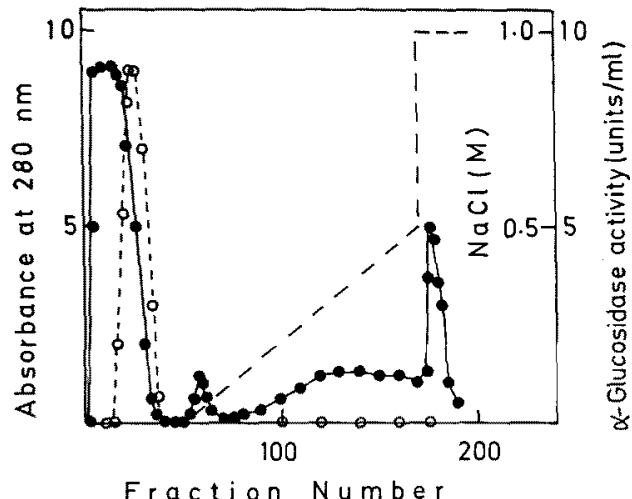

Fig. 1. DEAE-cellulose Column Chromatography. Applied protein, $3000 \mathrm{mg}$; flow rate, about $30 \mathrm{ml}$ per hr; fraction volume, $16.25 \mathrm{ml}$; - $\bullet$, absorbance at $280 \mathrm{~nm} ; 0--0, \alpha$-glucosidase activity; $-\cdots, \mathrm{NaCl}$ (mole).

$\mathrm{pH}$ 5.3. The solution was dialyzed overnight against $0.01 \mathrm{M}$ acetate buffer, $\mathrm{pH} 5.3$.

Step 4. Preparative gel electrofocusing. The solution obtained from Step 3 was subjected to preparative gel electrofocusing with $7.5 \%$ polyacrylamide gel containing carrier ampholyte (pH range, 4 to 6). The equipment was made up of a running column $(0.5 \phi \times$ $10 \mathrm{~cm}$ ) and two chambers. The running column was composed of $0.56 \mathrm{ml}$ of a sample gel and $1.2 \mathrm{ml}$ of a separating gel. The upper and lower chambers contained $300 \mathrm{ml}$ of $1 \%$ ethylenediamine aqueous solution and $300 \mathrm{ml}$ of $1 \%$ phosphoric acid aqueous solution, respectively. Electrofocusing was carried out at $80 \mathrm{~V}$ for $48 \mathrm{hr}$ with the anode in the lower chamber. After electrofocusing, one of the gels was stained and destained by the same procedure as described in MATERIALS AND METHODS. Sections of the unstained gel corresponding to protein bands in the stained gel were excised and crushed in $1 \mathrm{ml}$ of deionized water per a gel. The pH of the water suspension of each piece was measured with a HitachiHoriba model M-5 pH meter, and then the same volume of $1 \mathrm{M}$ acetate buffer, $\mathrm{pH} 5.3$, was added to the water suspension. After standing for 2 to $3 \mathrm{hr}$, the gel was removed by filtration. The active filtrates of $\alpha$-glucosidase were pooled and dialyzed overnight against $0.02 \mathrm{M}$

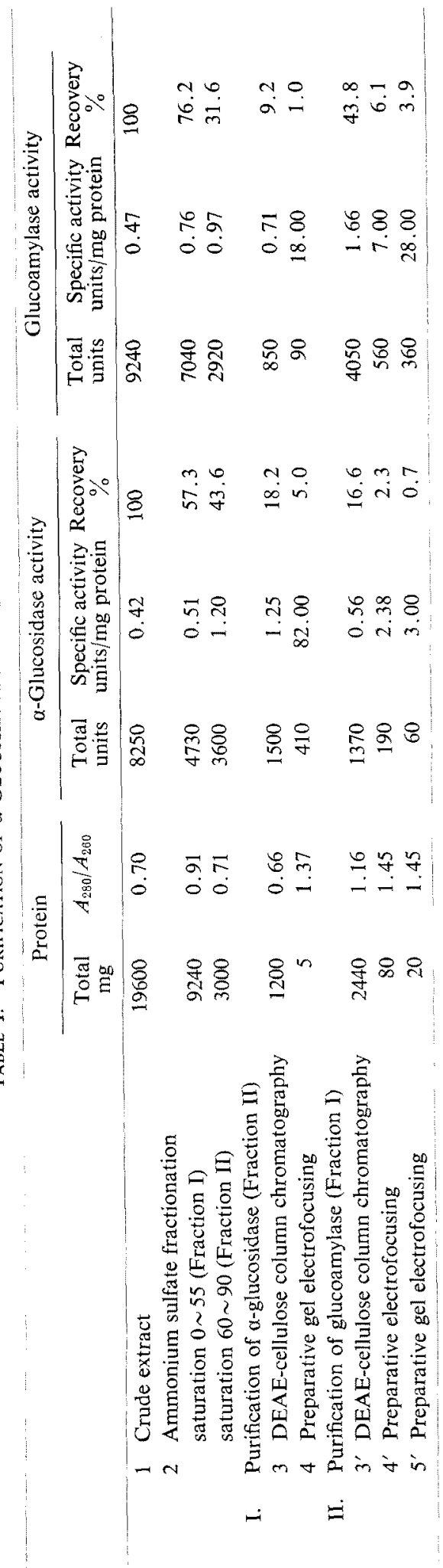


acetate buffer, pH 5.3. The solution was concentrated by ultrafiltration, using a collodion bag. The concentrate was dialyzed overnight against $0.02 \mathrm{M}$ acetate buffer, $\mathrm{pH}$ 5.3. A summary of the purification procedure is given in Table I.

\section{Purification of glucoamylase}

Step 3'. DEAE-cellulose column chromatography. After being dialyzed, Fraction I was chromatographed on a DEAE-cellulose column $(1.8 \phi \times 20 \mathrm{~cm})$ under the same conditions as described in Step 3, and ammonium sulfate was added to the active fractions (Nos. 52 to 110 ) to give $60 \%$ saturation (Fig. 2). The resulting precipitate was collected by centrifugation and dissolved in $0.05 \mathrm{M}$ acetate buffer, $\mathrm{pH}$ 5.3. The solution was dialyzed overnight against $0.01 \mathrm{~m}$ acetate buffer, $\mathrm{pH} 5.3$.

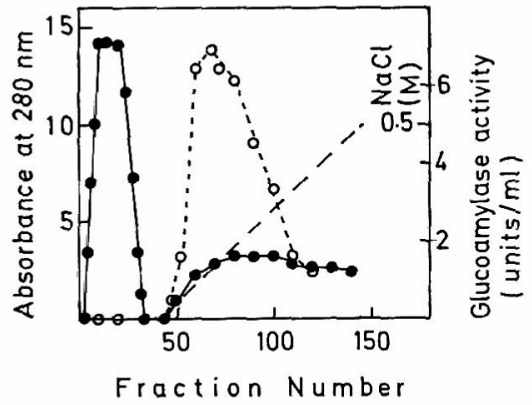

FIG. 2. DEAE-cellulose Column Chromatography.

Applied protein, $9240 \mathrm{mg}$; flow rate, about $30 \mathrm{ml}$ per $\mathrm{hr}$; fraction volume, $16.25 \mathrm{ml}$; $280 \mathrm{~nm}$; $\mathrm{O}---\mathrm{O}$, glucoamylase activity; ---, $\mathrm{NaCl}$ (mole).

Step 4'. Preparative electrofocusing. The solution obtained from Step 3' was applied to a column of $110 \mathrm{ml}$ capacity of an LKB 8100 Ampholine electrofocusing equipment with a density gradient of sucrose and a $\mathrm{pH}$ gradient of 4 to 6 . After electrofocusing for $24 \mathrm{hr}, 2 \mathrm{ml}$ fractions were collected from the bottom of the column by means of a peristaltic pump. The active fractions were combined, and concentrated by ultrafiltration using a Diafilter G-05 T. The concentrate was dialyzed for $48 \mathrm{hr}$ against two changes of 2 liters of $0.01 \mathrm{M}$ acetate buffer, pH 5.3.
Step 5'. Preparative gel electrofocusing. The solution obtained from Step $4^{\prime}$ was subjected to preparative gel electrofocusing by the same procedure as described in Step 4 except that $\mathrm{pH}$ range of carrier ampholyte used was 3 to 5 . The active filtrates of glucoamylase were pooled and dialyzed overnight against $0.02 \mathrm{M}$ acetate buffer, $\mathrm{pH}$ 5.3. The solution was concentrated by ultrafiltration, using a collodion bag. The concentrate was dialyzed overnight against $0.02 \mathrm{M}$ acetate buffer, $\mathrm{pH}$ 5.3. A summary of the purification procedure is given in Table $\mathrm{I}$.

\section{Criteria of purity}

1) Gel electrofocusing. The $\alpha$-glucosidase and glucoamylase preparations were homogeneous on gel electrofocusing (Fig. 3). The isoelectric point of the $\alpha$-glucosidase preparation was at $\mathrm{pH} 4.6$, and that of the glucoamylase, at $\mathrm{pH} 4.1$.

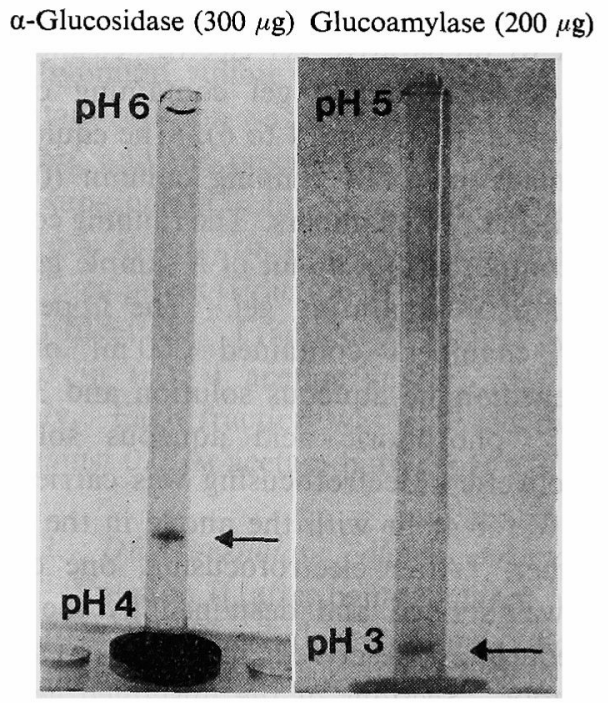

Fig. 3. Gel Electrofocusing of $\alpha-$ Glucosidase and Glucoamylase.

Gel electrofocusing was performed by the procedure as described in Materials AND Methods. Electrofocusing was run at a constant voltage of $80 \mathrm{~V}$ for $48 \mathrm{hr}$ at $4^{\circ} \mathrm{C}$ using a conventional disc electrophoretic apparatus with $0.5 \phi \times 8 \mathrm{~cm}$ tubes. Migration was towards anode.

2) Ultracentrifugation. The sedimentation patterns of the $\alpha$-glucosidase and the 


\section{$\alpha$-Glucosidase}

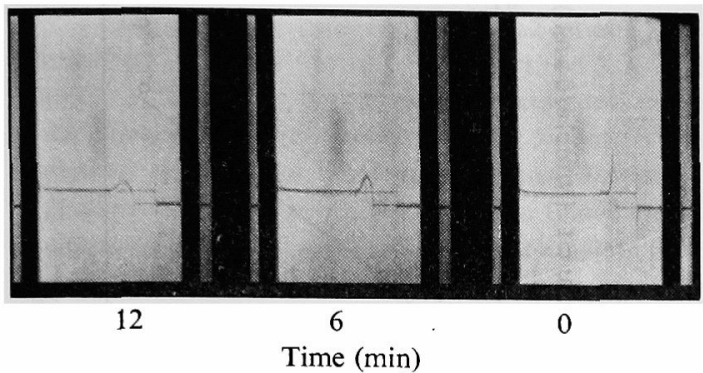

Glucoamylase

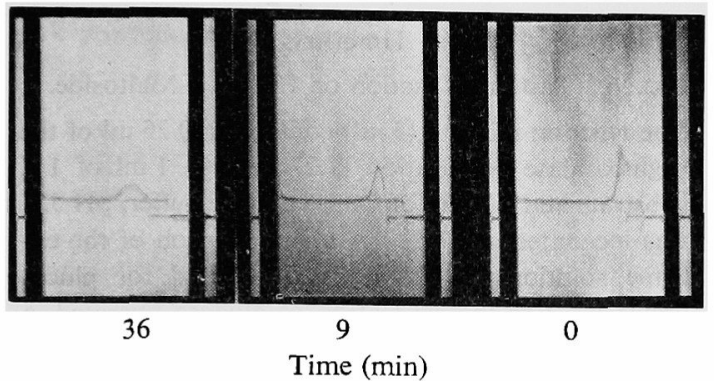

FIG. 4. Sedimentation Pattern of $\alpha$-Glucosidase and Glucoamylase.

Experimental conditions were as follows: temperature, $20^{\circ} \mathrm{C}$; speed, 58,000 rpm; bar angle, $70^{\circ}$; cell used, a standard $12 \mathrm{~mm}$ double sector cell. Pictures were taken at indicated times after maximum speed had been reached. The protein concentration was 1.87

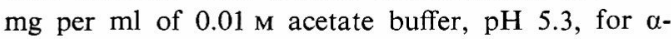
glucosidase, and $7.28 \mathrm{mg}$ per $\mathrm{ml}$ of $0.01 \mathrm{M}$ acetate buffer, $\mathrm{pH} \mathrm{5.3,} \mathrm{for} \mathrm{glucoamylase.}$

glucoamylase are illustrated in Fig. 4. The value of the sedimentation coefficient $\left(s_{20, \mathrm{w}}\right)$ was calculated to be $5.06 \mathrm{~S}$ for $\alpha$-glucosidase and $3.36 \mathrm{~S}$ for glucoamylase.

\section{Properties of enzyme}

1) Molecular weight. Molecular weight was determined by sodium dodecyl sulfatepolyacrylamide gel electrophoresis. From the data of Fig. 5, the molecular weights of $\alpha$ glucosidase and glucoamylase were calculated to be 51,000 and 55,000 , respectively.

2) $p H$ optimum, $p H$ stability, temperature optimum and heat stability. $\mathrm{pH}$ optimum, $\mathrm{pH}$ stability, temperature optimum and heat stability are shown in Table II.

3) Substrate specificity. The activities of

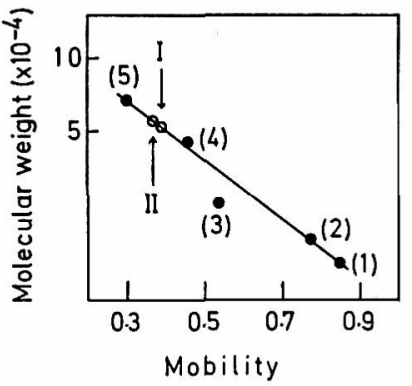

Fig. 5. Determination of the Molecular Weight of $\alpha$-Glucosidase and Glucoamylase.

SDS-polyacrylamide gel electrophoresis was performed as described in Materials and Methods.

I, $\alpha$-glucosidase; II, glucoamylase; (1), lysozyme; (2), myoglobin; (3), chymotrypsinogen A; (4), ovalbumin; (5), bovine serum albumin.

Table II. pH Optimum, pH Stability, Temperature Optimum, and Heat STABILITY

\begin{tabular}{|c|c|c|}
\hline & $\alpha$-Glucosidase & Glucoamylase \\
\hline pH Optimum & 5.0 & 4.5 \\
\hline pH Stability ${ }^{a}$ & $4.0 \sim 6.0$ & $3.5 \sim 5.5$ \\
\hline Temperature optimum & $50^{\circ} \mathrm{C}$ & $50^{\circ} \mathrm{C}$ \\
\hline Heat stability ${ }^{b}$ & up to $40^{\circ} \mathrm{C}$ & up to $40^{\circ} \mathrm{C}$ \\
\hline
\end{tabular}

a Enzyme was preincubated for $20 \mathrm{hr}$ at $30^{\circ} \mathrm{C}$ with $0.05 \mathrm{M}$ Mcllvaine's buffer at various $\mathrm{pH}$.

$b \quad$ Enzyme was preincubated for $15 \mathrm{~min}$ at various temperatures.

the $\alpha$-glucosidase and the glucoamylase were assayed with various substrates (Table III). The $\alpha$-glucosidase readily hydrolyzed maltose, phenyl $\alpha$-maltoside, maltotriose, amylose and soluble starch, and weakly isomaltose, and very slightly panose, amylopectin and glycogen. The glucoamylase hydrolyzed amylose, amylopectin, glycogen, soluble starch, and maltotriose. Although the glucoamylase hydrolyzed maltose, the rate of the hydrolysis was much lower than those for amylaceous polysaccharides. The limits of hydrolysis for polysaccharides were also tested (Table III).

4) Patterns of action on phenyl $\alpha$-maltoside and amylose. As shown in Fig. 6, the $\alpha$ glucosidase and the glucoamylase hydrolyzed phenyl $\alpha$-maltoside into glucose and phenyl $\alpha$-glucoside. The two enzymes produced glucose from amylose, and glucose was the 
Table III. Substrate Spectfictty

\begin{tabular}{|c|c|c|c|c|c|c|}
\hline \multirow[t]{2}{*}{ Substrate } & \multicolumn{2}{|c|}{$\begin{array}{c}\text { Relative } \\
\text { rate of } \\
\text { hydrolysis* } \\
(\%)\end{array}$} & \multicolumn{2}{|c|}{$\begin{array}{l}K m \text { value } \\
(\mathrm{mg} / \mathrm{ml})\end{array}$} & \multicolumn{2}{|c|}{$\begin{array}{l}\text { Limit of } \\
\text { hydrolysis } \\
(\%)\end{array}$} \\
\hline & $\mathbf{I}^{a}$ & $\mathrm{II}^{b}$ & $\mathrm{I}^{a}$ & $I^{b}$ & $\mathbf{I}^{a}$ & $I^{b}$ \\
\hline Amylopectin & 1.6 & 74.4 & & 0.250 & & 100 \\
\hline Amylose & 45.6 & 100 & 0.400 & 0.160 & 100 & 100 \\
\hline Glycogen & trace & 54.8 & & 0.210 & & 100 \\
\hline Soluble starch & 22.8 & 84.4 & & 0.134 & & 100 \\
\hline Maltotriose & 58.2 & 54.0 & & & & \\
\hline Panose & 2.6 & 3.7 & & & & \\
\hline \multicolumn{7}{|l|}{ Phenyl } \\
\hline$\alpha$-maltoside & 50.9 & 13.3 & & & & \\
\hline Isomaltose & 4.9 & trace & & & & \\
\hline Maltose & 100 & 13.6 & 0.190 & $(5.55 \times$ & $10^{-4} \Lambda$ & M) \\
\hline \multicolumn{7}{|l|}{ Phenyl } \\
\hline Sucrose & 0 & 0 & & & & \\
\hline Cellobiose & 0 & 0 & & & & \\
\hline Lactose & 0 & 0 & & & & \\
\hline
\end{tabular}

* The reaction mixture $(0.5 \mathrm{ml})$ containing enzyme solution, $0.1 \mathrm{ml}$ of $1 \%$ substrate, and $0.05 \mathrm{M}$ acetate buffer, pH 5.3, was incubated at $37^{\circ} \mathrm{C}$ for $15 \mathrm{~min}$. Enzyme solution used was as follows: a-glucosidase (0.582 units) and glucoamylase (0.583 units).

$a$ a-Glucosidase; $b$ Glucoamylase.

only detectable hydrolysis product. A linear relationship was observed between the degrees of dextrinization and hydrolysis of amylose. The degree of dextrinization was determined by the iodine color reaction. ${ }^{23}$ )

5) Raw starch digestion. The glucoamylase preparation was examined for glucoamylase activity toward boiled soluble starch, rice starch, buckwheat starch, corn starch, and potato starch (Table IV). For comparison, data for a glucoamylase from $R h$. niveus are also included.

6) Activities on oxidized amylose. The $\alpha$-glucosidase and the glucoamylase were examined for the enzyme activity toward amylose and oxidized amylose (Table V). For comparison, data for an $\alpha$-glucosidase from $M$. javanicus, a glucoamylase from $R h$. niveus, and the mixed solution of glucoamylase from $R h$. niveus and $\alpha$-amylase from $B$. subtilis (liquefying type) are also included. While all the enzyme preparations released glucose from

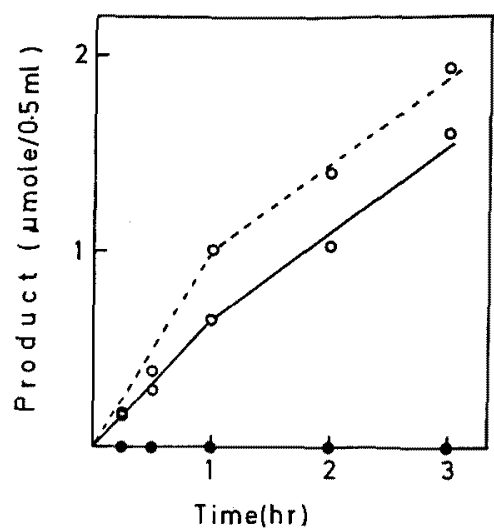

FIG. 6. Pattern of Action on Phenyl a-Maltoside.

The reaction mixture $(5 \mathrm{ml})$ containing $0.25 \mathrm{ml}$ of the a-glucosidase preparation (7.276 units), $1 \mathrm{ml}$ of $1 \%$ substrate and $3.75 \mathrm{ml}$ of $0.05 \mathrm{M}$ acetate buffer, $\mathrm{pH} 5.3$, was incubated at $37^{\circ} \mathrm{C}$. A $0.3 \mathrm{ml}$ portion of the enzyme solution (33.028 units) was used for glucoamylase. For the estimation of glucose liberated, a portion of the reaction mixture was pipetted out at various time intervals, and heated in a boiling water bath for $5 \mathrm{~min}$. For the estimation of phenol liberated, a portion of the reaction mixture was pipetted out at various time intervals, and the reaction was stopped by pouring into $2 \mathrm{ml}$ of $5 \% \mathrm{Na}_{2} \mathrm{CO}_{3}$ $0-0$, glucose liberated by $\alpha$-glucosidase; phenol liberated by $\alpha$-glucosidase; $\bigcirc--\bigcirc$, glucose liberated by glucoamylase; ---0, phenol liberated by glucoamylase.

\section{Table IV. Activities of Glucoamylases on}

Raw Starch and Bolled Soluble Starch

The reaction mixture containing $10 \mathrm{mg}$ of raw starch, glucoamylase solution, and $0.05 \mathrm{M}$ acetate buffer, $\mathrm{pH} 5.3$, in a final volume of $5.0 \mathrm{ml}$ was incubated at $37^{\circ} \mathrm{C}$ for $60 \mathrm{~min}$ under shaking conditions. Soluble starch dissolved in deionized water in a concentration of $1 \%$ was used as the substrate. The amounts of glucoamylase and glucoamylase from $R h$. niveus (pure type) used were $0.5 \mathrm{ml}$ (8.250 units) and $0.04 \mathrm{ml}$ (12.420 units), respectively.

\begin{tabular}{|c|c|c|}
\hline $\begin{array}{l}\text { Enzyme } \\
\text { Substrate }\end{array}$ & \multicolumn{2}{|c|}{$\begin{array}{r}(R h . \text { niveus }) \\
\text { relative rate of hydrolysis }(\%)\end{array}$} \\
\hline Boiled soluble starch & 100 & 100 \\
\hline Rice starch & 2.2 & 7.2 \\
\hline Buckwheat starch & 1.1 & 4.6 \\
\hline Corn starch & 2.7 & 3.7 \\
\hline Potato starch & 0.6 & 0.4 \\
\hline
\end{tabular}

amylose in the yield of approximately complete hydrolysis, there was a considerable difference in the release of glucose from the 
Table V. Activities of $\alpha$-Glucosidase and Glucoamylase on Oxidized Amylose

The reaction mixture containing $0.2 \mathrm{ml}$ of $1 \%$ oxidized amylose solution (or amylose solution), enzyme solution, $0.1 \mathrm{ml}$ of $0.5 \mathrm{M}$ acetate buffer, $\mathrm{pH} 5.3$, and deionized water in a final volume of $1.0 \mathrm{ml}$ was incubated at $37^{\circ} \mathrm{C}$. A portion of the reaction mixture was pipetted out at various time intervals and stopped by heating the mixture in a boiling water bath for $5 \mathrm{~min}$. The amount of glucose formed was determined by the same method as described in MAterials and Methods. The amounts of enzymes used were as follows: $a-$ glucosidase (7.420 units), glucoamylase (2.600 units), M. javanicus $\alpha$-glucosidase (15.349 units), Rh. niveus glucoamylase (8.458 units), $B$. subtilis $\alpha$-amylase (0.2 units).

\begin{tabular}{|c|c|c|c|c|c|c|}
\hline \multicolumn{2}{|c|}{ Enzyme } & \multicolumn{2}{|c|}{ L. edodes (Berk.) Sing. } & \multirow{2}{*}{$\begin{array}{c}\text { M. javanicus } \\
\begin{array}{c}\alpha-\text { Gluco- } \\
\text { sidase } \\
\%\end{array}\end{array}$} & \multicolumn{2}{|c|}{ Rh. niveus glucoamylase } \\
\hline & Substrate & $\begin{array}{c}\alpha-\text { Gluco- } \\
\text { sidase } \\
\%\end{array}$ & $\begin{array}{l}\text { Gluco- } \\
\text { amylase } \\
\% \\
\%\end{array}$ & & $\begin{array}{c}\text { + none } \\
\%\end{array}$ & $\begin{array}{c}+B \text {. subtilis } \\
\alpha \text {-amylase }\end{array}$ \\
\hline \multirow[t]{3}{*}{ Amylose } & 1. $15 \mathrm{~min}$ & 23.0 & 26.0 & 72.3 & 82.4 & 66.8 \\
\hline & 2. $30 \mathrm{~min}$ & 33.5 & 43.7 & 79.1 & 94.7 & 73.0 \\
\hline & 3. $3 \mathrm{hr}$ & 98.7 & 100.2 & 97.5 & 97.4 & 108.6 \\
\hline \multirow{7}{*}{$\begin{array}{l}\text { Oxidized } \\
\text { amylose }\end{array}$} & 1. $15 \mathrm{~min}$ & 20.3 & 24.0 & 42.0 & 42.9 & 44.5 \\
\hline & 2. $30 \mathrm{~min}$ & 29.6 & 40.0 & 39.2 & 41.7 & 49.8 \\
\hline & 3. $60 \mathrm{~min}$ & 37.2 & 40.7 & 42.0 & 50.0 & 54.3 \\
\hline & 4. $3 \mathrm{hr}$ & 39.5 & 41.0 & 43.2 & 48.8 & 66.8 \\
\hline & 5. $5 \mathrm{hr}$ & 49.0 & 41.3 & 46.0 & 47.9 & 64.0 \\
\hline & 6. $9 \mathrm{hr}$ & 49.2 & 43.7 & 46.0 & 54.2 & 69.2 \\
\hline & 7. $23 \mathrm{hr}$ & 49.5 & 45.6 & 46.0 & 55.0 & 76.1 \\
\hline
\end{tabular}

$\%$ : hydrolysis degree of substrate.

oxidized amylose between a glucoamylase from $R h$. niveus and the other enzymes. The glucoamylase from $R h$. niveus and the mixed solution of $R h$. niveus glucoamylase and $B$. subtilis $\alpha$-amylase continued to release glucose from the oxidized amylose after approximately $50 \%$ hydrolysis. In contrast the release of glucose by the enzyme preparations from $L$. edodes (Berk.) Sing. and $M$. javanicus diminished to a negligibly low rate after approximately $50 \%$ hydrolysis of the oxidized amylose. It is assumed that the enzyme preparations from L. edodes (Berk.) Sing. and $M$. javanicus did not contain $\alpha$-amylase.

7) $\alpha$-Glucosyltransfer products. When the $\alpha$-glucosidase was incubated with $5 \%$ maltose, unknown substances (temporarily named $X_{1}$, $\mathrm{X}_{2}$, and $\mathrm{X}_{3}$ ) were detected on a paper chromatogram (Fig. 7). As shown in Fig. 7, the main product, $\mathrm{X}_{2}$, was presumed to be maltotriose on the basis of the similarities in the paper chromatographic mobility.

8) Anomeric configuration of fission products. Time-course of the reaction of the $\alpha$-glucosidase and the glucoamylase with

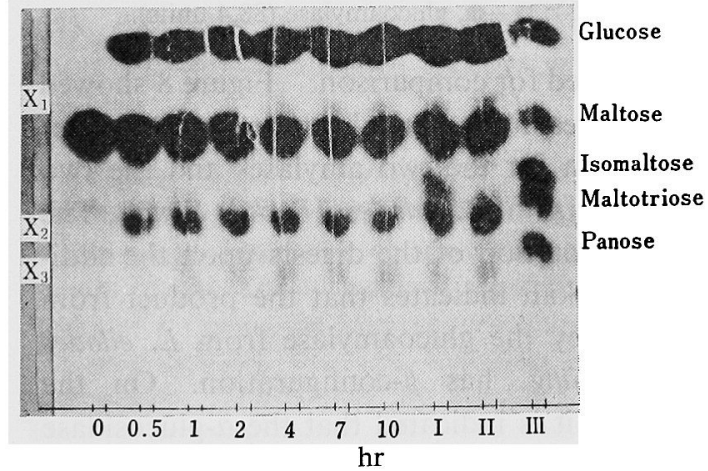

FIG. 7. A Paper Chromatogram of Transglucosylation Products from Maltose.

The reaction mixture $(2 \mathrm{ml})$ containing $0.1 \mathrm{ml}$ of the $\alpha$-glucosidase preparation (24.12 units), $1 \mathrm{ml}$ of $10 \%$ maltose, $0.5 \mathrm{ml}$ of $0.1 \mathrm{M}$ acetate buffer, $\mathrm{pH} 5.3$, and $0.4 \mathrm{ml}$ of deionized water was incubated at $37^{\circ} \mathrm{C}$. At various time intervals, $0.05 \mathrm{ml}$ of the reaction mixture was chromatographed by the same procedure as described in MAterials AND Methods.

$\mathrm{I}$, the reaction mixture $(10 \mathrm{hr})+$ isomaltose $(100 \mu \mathrm{g})$; II, the reaction mixture $(10 \mathrm{hr})+$ maltotriose $(200 \mu \mathrm{g})$; III, glucose $(60 \mu \mathrm{g})+$ maltose $(150 \mu \mathrm{g})+$ isomaltose $(150 \mu \mathrm{g})+$ maltotriose $(300 \mu \mathrm{g})+$ panose $(300 \mu \mathrm{g})$.

amylose was investigated by following the changes in the optical rotation. Two other amylases, from $B$. subtilis and $R h$. niveus, were 


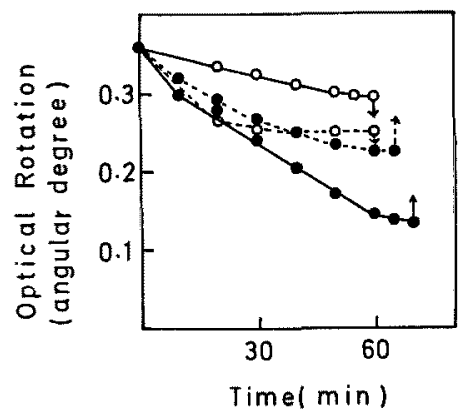

Fig. 8. Optical Rotation Study.

The mixture $(25 \mathrm{ml})$ containing $5.0 \mathrm{ml}$ of $1 \%$ amylose aqueous solution, enzyme solution and deionized water was incubated at $40^{\circ} \mathrm{C}$. The measurements of optical rotation were made at various intervals with a Yanaco model OR-50 automatic polarimeter, a 10 $\mathrm{cm}$-light pathway length cell being used. When the rotation became constant, $10 \mathrm{mg}$ of anhydrous sodium carbonate was added to $25 \mathrm{ml}$ of the digest, the $\mathrm{pH}$ being brought to 10 . The arrow indicates the optical rotation after the addition of alkali to the digests.

O-m O, B. subtilis a-amylase (173.7 units); --.-, $R h$. niveus glucoamylase (77.6 units); $0-0, \alpha$-glucosidase (168.2 units); - glucoamylase (88.4 units).

also studied for comparison. Figure 8 showed the changes in the optical rotation with time of incubation for the two amylases and the two enzymes from L. edodes (Berk.) Sing. The upward rotation of the digests upon the addition of alkali indicates that the product from amylose by the glucoamylase from $L$. edodes (Berk.) Sing. has $\beta$-configuration. On the contrary, it is indicated that the $\alpha$-glucosidase from L. edodes (Berk.) Sing. produces $\alpha$ glucose from amylose.

9) Inhibitor. Among the metal ions tested, $\mathrm{Cu}^{2+}, \mathrm{Hg}^{2+}, \mathrm{Pb}^{2+}$ and $\mathrm{Zn}^{2+}$ were the potent inhibitors for the $\alpha$-glucosidase, and $\mathrm{Al}^{3+}, \mathrm{Hg}^{2+}$ and $\mathrm{Pb}^{2+}$ for the glucoamylase. They were also inhibited by Tris (Table VI).

\section{DISCUSSION}

An a-glucosidase and a glucoamylase from L. edodes (Berk.) Sing. were isolated in highly purified forms by a procedure including fractionation with ammonium sulfate, DEAEcellulose column chromatography and pre-
Table VI. Effect of Metal Ions and SEVERAL ENZYME INHIBITORS

For the assay of the effect of metal ions, enzyme solution, $0.02 \mathrm{ml}$ of $0.1 \mathrm{M}$ metal ion solution in deionized water, and $0.05 \mathrm{M}$ acetate buffer, $\mathrm{pH} 5.3$, in a final volume of $0.4 \mathrm{ml}$ were preincubated at $37^{\circ} \mathrm{C}$ for $30 \mathrm{~min}$. After preincubation, $0.1 \mathrm{ml}$ of $1 \%$ maltose (soluble starch for glucoamylase) was added and the resulting mixture was kept at $37^{\circ} \mathrm{C}$ for $15 \mathrm{~min}$.

For the assay of the effect of several inhibitors, the enzyme solution, $0.2 \mathrm{ml}$ of $0.1 \mathrm{M}$ acetate buffer, $\mathrm{pH}$ 5.3 , each of the reagents dissolved in deionized water, and deionized water in a final volume of $0.4 \mathrm{ml}$ were preincubated at $37^{\circ} \mathrm{C}$ for $5 \mathrm{~min}$. To the mixture was added $0.1 \mathrm{ml}$ of $1 \%$ maltose (soluble starch for glucoamylase) and the resulting mixture was kept at $37^{\circ} \mathrm{C}$ for $15 \mathrm{~min}$.

Enzyme solution used was as follows: $\alpha$-glucosidase (0.582 units) and glucoamylase (0.583 units).

\begin{tabular}{|c|c|c|c|}
\hline \multirow[t]{2}{*}{$\begin{array}{l}\text { Metal ion } \\
\text { or inhibitors }\end{array}$} & $\begin{array}{l}\text { Concentra- } \\
\text { tion }\end{array}$ & \multicolumn{2}{|c|}{$\begin{array}{l}\text { Hydrolysis (residual } \\
\text { activity, \%) }\end{array}$} \\
\hline & $\mathrm{mM}$ & $\begin{array}{l}\alpha \text {-Gluco- } \\
\text { sidase }\end{array}$ & $\begin{array}{l}\text { Gluco- } \\
\text { amylase }\end{array}$ \\
\hline None & & 100 & 100 \\
\hline $\mathrm{AlCl}_{3}$ & 5 & 71.3 & 66.3 \\
\hline $\mathrm{BaCl}_{2} \cdot 2 \mathrm{H}_{2} \mathrm{O}$ & 5 & 81.2 & 98.1 \\
\hline $\mathrm{CaCl}_{2}$ & 5 & 83.7 & 99.1 \\
\hline $\mathrm{CoCl}_{2}$ & 5 & 70.6 & 87.2 \\
\hline $\mathrm{Cu}\left(\mathrm{CH}_{3} \mathrm{COO}\right)_{2}$ & 5 & 21.3 & 81.9 \\
\hline $\mathrm{HgCl}_{2}$ & 5 & 2.5 & 70.7 \\
\hline $\mathrm{KCl}$ & 5 & 81.2 & 100.5 \\
\hline $\mathrm{MgCl}_{2}$ & 5 & 87.2 & 97.0 \\
\hline $\mathrm{MnCl}_{2}$ & 5 & 90.1 & 100.5 \\
\hline $\mathrm{NaCl}$ & 5 & 94.7 & 92.3 \\
\hline $\mathrm{NiCl}_{2}$ & 5 & 85.5 & 88.8 \\
\hline $\mathrm{Pb}\left(\mathrm{CH}_{3} \mathrm{COO}\right)_{2}$ & 5 & 15.2 & 74.4 \\
\hline $\mathrm{ZnCl}_{2}$ & 5 & 11.3 & 96.7 \\
\hline EDTA & 5 & 83.7 & 82.6 \\
\hline $\begin{array}{l}\text { Monoiodo- } \\
\text { acetic acid }\end{array}$ & 0.05 & 105.0 & 117.9 \\
\hline PCMB & 0.05 & 59.6 & 78.9 \\
\hline Tris & 50 & 53.8 & 50.4 \\
\hline Turanose & 14.6 & 50.0 & 109.8 \\
\hline
\end{tabular}

parative gel electrofocusing. The two enzymes were homogeneous as judged by polyacrylamide gel electrofocusing and in ultracentrifugation. The $\alpha$-glucosidase readily hydrolyzed maltose, maltotriose, phenyl $\alpha$-maltoside, amylose, soluble starch, and weakly isomaltose. $\alpha$-Glucosidases from plants, $\left.{ }^{23} 25\right) \quad M$. javanicus, $^{26)}$ M. racemosus, ${ }^{27)}$ Pen. purpurogenum, ${ }^{3)}$ Pen. oxalicum, ${ }^{4)}$ and pig liver ${ }^{28)}$ are known to 
hydrolyze soluble starch, whereas $\alpha$-glucosidase from Asp. niger ${ }^{87}$ has no or very slight hydrolytic activity toward the substrate. In the substrate specificity, the $\alpha$-glucosidase from $L$. edodes (Berk.) Sing. seems to be similar to the $\alpha$-glucosidases from Mucor sp. and Penicillium sp., but different from those obtained from Aspergillus sp. Like $\alpha$-glucosidases from $M$. javanicus, ${ }^{26)} M$. racemosus, ${ }^{27)}$ Pen. purpurogenum, ${ }^{3)}$ pig liver, ${ }^{28)}$ and $B$. cereus, ${ }^{29)} \alpha-$ glucosidase from $L$. edodes (Berk.) Sing. formed maltotriose as the main $a$-glucosyltransfer product from maltose. In contrast, isomaltose was the main $\alpha$-glucosyltransfer product, when $a$-glucosidases from Asp. niger, ${ }^{81}$ Asp. oryzae, ${ }^{9 /}$ Asp. awamori, ${ }^{7)}$ Schizosaccharomyces pombe, ${ }^{30)}$ and buckwheat ${ }^{23}$ were incubated with maltose. From the experimental results reported here and in the previous papers, it has been found that $\alpha$ glucosidases from fungi can be classified into at least three groups according to their starchdegrading activities and their modes of transglucosylation action. The enzymes of the first group readily hydrolyze soluble starch and produce maltotriose as the main $\alpha$-glucosyltransfer product from maltose, as exemplified by $\alpha$-glucosidases from $M$. javanicus, $M$. racemosus, Pen. purpurogenum and $L$. edodes (Berk.) Sing. The second group is composed of $\alpha$-glucosidase from Pen. oxalicum which catalyzes the transfer of the $\alpha$-glucosyl group from maltose to give isomaltose and panose, in addition to its hydrolytic activity for soluble starch. The third group includes a-glucosidases from Asp. niger, Asp. oryzae, Asp. fumigatus ${ }^{31)}$ and Asp. awamori. They hydrolyze soluble starch very weakly or not, and catalyze the transfer of the $\alpha$-glucosyl residue of maltose predominately to the primary alcohol groups of the acceptor saccharides to produce isomaltose and panose.

The glucoamylase from $L$. edodes (Berk.) Sing. readily hydrolyzed amylose, amylopectin, glycogen, and soluble starch, converting them almost quantitatively into glucose. The complete hydrolysis of amylopectin and glycogen strongly suggests that the enzyme has the ability to cleave $\alpha-1,6$-glucosidic linkage of higher molecular substrates. The enzyme hydrolyzed maltose at a much lower rate than amylaceous polysaccharides. It hydrolyzed phenyl $\alpha$-maltoside into glucose and phenyl $\alpha$-glucoside, and degraded the raw starch preparations at the lower rate than glucoamylase from $R h$. niveus. The enzyme from L. edodes (Berk.) Sing. hydrolyzed corn starch at the most rapid rate of the raw starch tested, whereas glucoamylases from $R h$. niveus, Pen. oxalicum ${ }^{4)}$ and $A s p$. awamori $i^{71}$ hydrolyzed rice starch most rapidly.

The changes in the optical rotation of the amylose digests upon the addition of alkali indicated that the $\alpha$-anomer of glucose was produced when the $\alpha$-glucosidase hydrolyzed amylose liberating glucose. On the other hand, the glucoamylase hydrolyzed amylose liberating $\beta$-glucose. $\alpha$-Glucosidase and glucoamylase seem to resemble each other in the hydrolytic pattern of amylose, but they are very different in the configuration of the anomeric carbon atom of glucose which they produce.

Acknowledgments. The authors wish to express their thanks to Assistant Professor K. Kawazu, Faculty of Agriculture, Okayama University for the use of Yanaco model OR-50 automatic polarimeter and Professor J. Ozawa, the Institute for Agricultural and Biological Sciences, Okayama University for his encouragement. The authors are grateful to Miss A. Mino for her experimental assistance in this work.

\section{REFERENCES}

1) Y. Yamasaki, T. Miyake and Y. Suzuki, Agric. Biol. Chem., 37, 131 (1973).

2) Y. Yamasaki, Y. Suzuki and J. Ozawa, ibid., 41, 1553 (1977).

3) Y. Yamasaki, Y. Suzuki and J. Ozawa, ibid., 40, 669 (1976).

4) Y. Yamasaki, Y. Suzuki and J. Ozawa, ibid., 41, 1451 (1977).

5) Y. Yamasaki, Y. Suzuki and J. Ozawa, ibid., 41, 2149 (1977).

6) A. Tsuboi, Y. Yamasaki and Y. Suzuki, ibid., 38, 543 (1974).

7) Y. Yamasaki, Y. Suzuki and J. Ozawa, ibid., 41, 755 (1977).

8) Y. Tsujisaka and J. Fukumoto, Symp. Enz. 
Chem. Japan, 13, 84 (1958).

9) S. Sugawara, Y. Nakamura and T. Shimomura, Bull. Agric. Chem. Soc. Jpn., 23, 156 (1959).

10) J. Fukumoto, Y. Tsujisaka and K. Minamii, Sci. Ind. (Japan), 28, 92 (1954).

11) S. Hayashida, Bull. Agric. Chem. Soc. Jpn., 21 , 386 (1957).

12) Y. Tsujisaka, J. Fukumoto and T. Yamamoto, Nature, 181, 770 (1958).

13) T. Fukui and Z. Nikuni, Agric. Biol. Chem., 33, 884 (1969).

14) N. M. Papadopoulos and W. C. Hess, Arch. Biochem. Biophys., 88, 167 (1960).

15) A. Dahlquist, Biochem. J., 80, 547 (1961).

16) O. Folin and V. Ciocalteu, J. Biol. Chem., 73, 627 (1927).

17) O. Warburg and W. Christian, Biochem. $Z$, 310, 384 (1941).

18) C. W. Wrigley, J. Chromatogr., 36, 362 (1968); idem, Science Tools, 15, 17 (1968).

19) K. Weber and M. Osborn, J. Biol. Chem., 244,
4406 (1969).

20) N. E. Welker and L. L. Campbell, J. Bacteriol, 86, 681 (1963).

21) J. J. Marshall and W. J. Whelan, Anal. Biochem., 43, 316 (1971).

22) T. Yamamoto, M. Ukawa and J. Fukumoto, Amylase Symposium, 4, 11 (1969).

23) M. Takahashi and T. Shimomura, Agric. Biol. Chem., 32, 929 (1968).

24) N. Takahashi, T. Shimomura and S. Chiba, ibid., 35, 2015 (1971).

25) S. Chiba and T. Shimomura, ibid., 39, 1041 (1975).

26) Y. Yamasaki, T. Miyake and Y. Suzuki, ibid., 37, 251 (1973).

27) Y. Yamasaki, Y. Suzuki and J. Ozawa, ibid,, 41, 1559 (1977).

28) K. Uchida and Y. Suzuki, ibid., 38, 195 (1974).

29) Y. Yamasaki and Y. Suzuki, ibid., 38, 443 (1974).

30) S. Chiba and T. Shimomura, ibid., 30, 536 (1966).

31) M. J. Rudick and A. D. Elbein, Arch. Biochem. Biophys., 161, 281 (1974). 